\title{
Specifying Some Quality Characteristics of Monofloral and Multifloral Honey Samples
}

\author{
Monofloral ve Multifloral Bal Numunelerinin Bazı Kalite \\ Kriterlerinin Belirlenmesi
}

\author{
Research Article
}

Nesrin Ece Bayram ${ }^{1,2 *}$ and Esra Demir ${ }^{3}$

'Bayburt University, Aydıntepe Vocational College, Department of Food Processing, Bayburt, Turkey, ${ }^{2}$ Bayburt University Beekeeping Research, Development and Application Center, Bayburt, Turkey.

${ }^{3}$ Recep Tayyip Erdoğan University Central Research Laboratory Application and Research Center, Rize, Turkey.

\section{A B S TRACT}

n this study, the aim was to examine honey samples from different origins with two important methods that are used especially in distinguishing the purity and origin of honey. For this purpose, proline and melissopalynological analyses of honey samples obtained from four different regions of Turkey (Erzurum, Giresun, Hakkari, Rize) were performed. The melissopalynological analyses of the samples were carried out with a light microscope. Proline analysis was performed using the spectrophotometric method. As a result of melissopalynological analyses, samples of monofloral and multifloral flower honey were encountered. The proline ratios of honey samples ranged from $503.46 \mathrm{mg} / \mathrm{kg}$ to $696.09 \mathrm{mg} / \mathrm{kg}$. In conclusion, as a result of melissopalynological analyses, proline content of honey samples that were determined to be chestnut honey was generally found to be lower.

\section{Key Words}

Honey, melissopalynological analysis, pollen, proline, bee product.

\section{öz}

u çalışmada özellikle balın safı̆̆ını ve orijinlerini ayırt etme noktasında kullanılan iki önemli yöntem ile farkIı orijinlerden bal örneklerinin incelenmesi amaçlanmıştır. Bu amaçla Türkiye'nin dört farklı bölgesinden (Erzurum, Giresun, Hakkari, Rize) elde edilen bal örneklerinin prolin analizi ve melissopalinolojik analizleri gerçekleştirilmiştir. Örneklerin melissopalinolojik analizleri ışık mikroskobu aracılığıyla yapılmıştır. Prolin analizleri ise, spektrofometrik yöntem kullanılarak yürütülmüştür. Melissopalinolojik analizler sonucunda monofloral ve multifloral çiçek balı örneklerine rastlanılmıştır. Bal örneklerinin prolin oranları 503.46 mg/kg-696.09 mg/ kg arasında değişkenlik göstermiştir. Sonuç olarak, melissopalinolojik analizler neticesinde kestane balı olduğu tespit edilen bal örneklerinin prolin içeriğinin genellikle daha düşük olduğu tespit edilmiştir.

\section{Anahtar Kelimeler}

Bal, melissopalinolojik analiz, polen, prolin, arı ürünü.

Article History: Received: May 28, 2018; Revised: Jun 12, 2018; Accepted: Jul 6, 2018; Available Online: Oct 4, 2018.

DOI: $10.15671 /$ HJBC.2018.249

Correspondence to: N. Ecem Bayram, Bayburt Uni., Aydıntepe Voc. College, Department of Food Processing, Bayburt, Turkey, 


\section{INTRODUCTION}

Trof urkey has a very important position in terms of beekeeping due to its climate diversity and its flora richness. In general, production of honey from bee products is carried out intensively in Turkey. Because honey has been consumed extensively since old times as an important food and a health protector. According to the source of nectar collected by bees, there are two main groups of honey, flower honey and honeydew honey. The source of flower honey is nectar of plants' flowers and there are several varieties of this honey such as linden, clover, citrus, cotton, thyme and acacia honey. The source of honeydew honey is the secretion of plants or insects living on the plant and pine, oak and fir honey are examples of this group [1].

Plant sources affect many physicochemical properties of honey such as appearance, color, water activity of honey, but also cause changes in its chemical content. Numerous studies have been conducted to investigate the composition of honey and its beneficial effects, especially in medical practice $[2,3]$. Most of its chemical content is composed of glucose and fructose carbohydrates. Apart from this, approximately 200 minor components such as pollen, minerals, vitamins, flavonoids, amino acids and proteins have been detected in the chemical structure of honey $[4,5]$.

There are quality parameters for honey, such as hydroxymethylfurfural content, moisture content, enzymatic activities and pesticide levels, but these parameters do not have a relationship with the geographical or botanical origin of honey [6]. Although melissopalynological analyses are used extensively for the identification of honey [79] this technique is tiring and requires taxonomic expertise. Therefore, results obtained from many marker and physicochemical analyses including amino acid profile are suggested [10, 11].

Although proteins are generally found in low concentrations in honey, they can be used as indicators in determining its identity [12]. In addition, protein content may be a bioactive indicator that contribute to the pharmacological activities of honey [12-14].
Since the main source of amino acids in honey is pollen, the amino acid profile of honey is also a characteristic of its botanical source [6]. However, the main source of amino acids in honey can be attributed to plant and animal sources, so amino acids in honey may be associated with the botanical origin [11]. There are amino acids such as proline, lysine, histidine, arginine, aspartic acid, serine, glutamic acid, glycine, alanine, cystine, valine, methionine, isoleucine, leucine, tyrosine, phenylalanine and tryptophan in honey [15-17]. Proline, one of these amino acids, makes up more than half the amount of amino acids in honey and added by bees to honey during the conversion of nectar to honey. The amount of proline in honey is an indicator that reflects the maturity level of honey, along with other components related to the bee like saccharose and glucosoxidase activities $[6,18]$. Proline is used as a criterion in the distinguishing honey obtained from nectar with honey obtained from bees fed with sugar syrup because it is an amino acid found in various amounts $(222 \mathrm{mg} / \mathrm{kg}$ in acacia, $956 \mathrm{mg} / \mathrm{kg}$ in thyme) in different plants [19]. For this reason, the ratio of proline amino acid is used as a criterion in distinguishing pure honey. Therefore, in this study, we aimed to investigate the proline ratios of honey produced in different locations and their plant origins and to obtain information about the purity and quality of honey samples.

\section{MATERIALS and METHODS Honey samples}

The honey samples were collected from different apiaries in Erzurum $(n=1)$, Giresun $(n=1)$, Hakkari $(n=1)$ and Rize $(n=5)$ in 2017 (Figure 1). Honey samples were obtained directly from the beekeepers.

\section{Melissopalynological Analysis of Honey Samples \\ Preparation of Pollen Preparations}

The pollen spectra of honey samples were determined with melissopalynological analysis according to the methodology described by Louveaux et al. [20] and Çelemli et al. [21]. Primarily, $10 \mathrm{~g}$ of stock honey samples mixed with a glass rod were taken and transferred to the test tube and then $20 \mathrm{ml}$ of distilled water was added. The test tubes were placed in a water bath at 


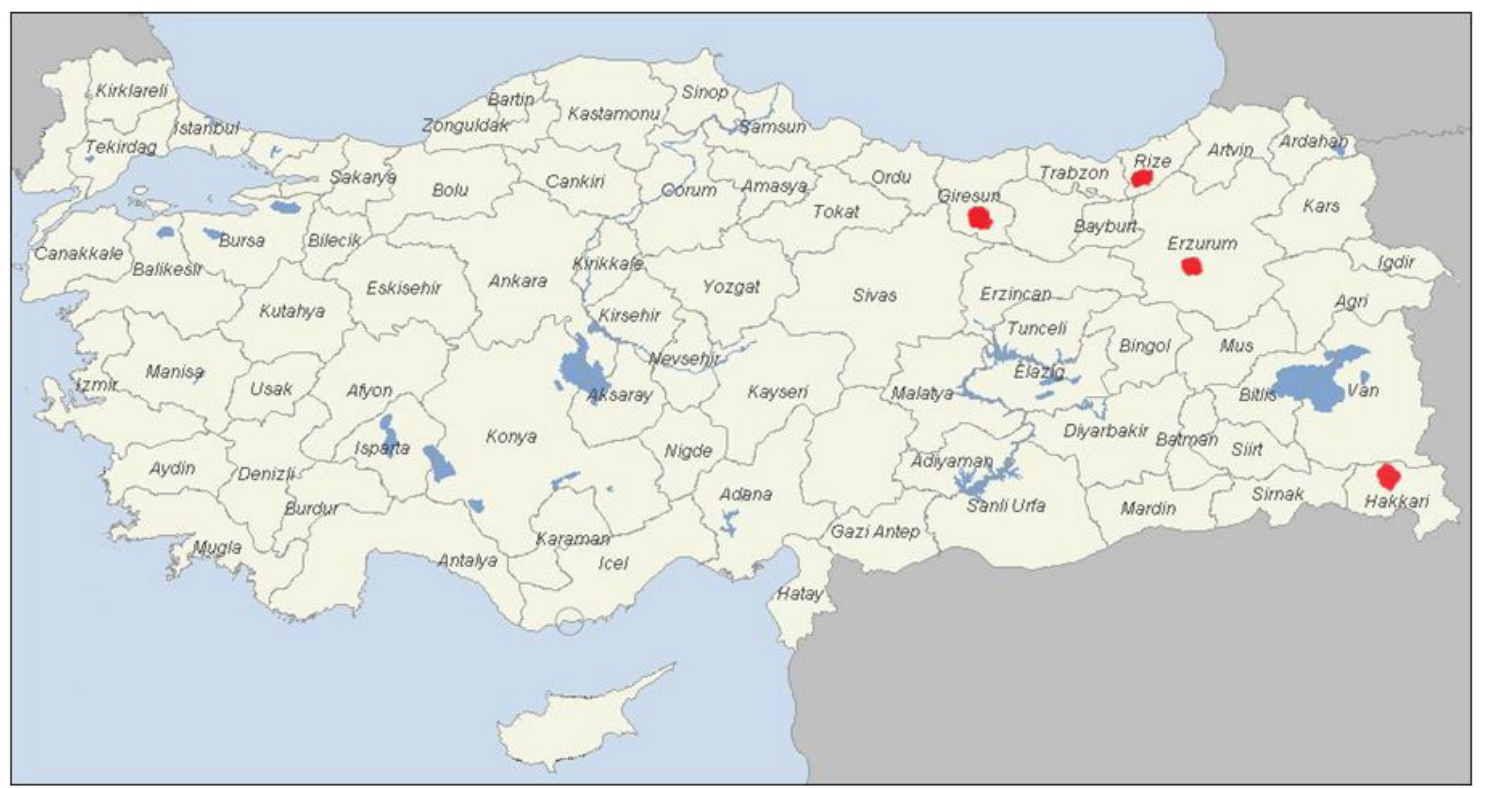

Figure 1. Location of Giresun, Rize, Erzurum and Hakkari regions in Turkey.

about $45^{\circ} \mathrm{C}$ for $10-15$ minutes. This suspension was centrifuged at $3500 \mathrm{rpm}$ for 45 minutes and then supernatant liquid was then poured off. The precipitate remaining in the bottom of the tube was infused with a quantity of basic-fuchsin added glycerin-gelatine taken from the needle tip, and this material was transferred onto the slide. The slide was heated at $30-40{ }^{\circ} \mathrm{C}$ and the $18 \times 18$ lamella was covered on top of it. The preparation was allowed to stand for about 12 hours as reverse.

\section{Identification of Plant Sources}

Honey samples prepared as described under heading "preparation of pollen preparations" was examined with a Leica DM500 light microscope and then, observed pollen types were classified into three categories: dominant pollen $(\geq 45 \%)$, secondary pollen (16-44\%), important minor pollen $(>3-15 \%)$ and rare pollen $(3 \%<)$. If a pollen type was observed more than $45 \%$ in a honey sample, this honey sample was classified as monofloral flower honey. Although this classification is a generalization, for example, for the classification of chestnut honey as a monofloral honey it must contain $70 \%$ to $90 \%$ of Castanea sativa pollen [22].

\section{Proline Content}

Proline content was analyzed according to the harmonised methods of the international honey commission [23] by spectrophotometric method. The absorbance of proline was titrimetrically read by a spectrophotometer at $520 \mathrm{~nm}$ by allowing it to react with ninhydrin.

\section{Moisture Content}

Moisture content of the honey samples was measured by using a portable refractometer according to the method of Devillers et al. [24] and Bogdanov [25].

\section{RESULTS and DISCUSSION}

Honeys produced in different regions have different characteristics due to plant diversity. Plant sources of honey is very important for determining its floral origin. In addition, against the increasing adulteration events in recent years, determination of pollen content of honey is used for the detection of counterfeiting.

Pollens of Castanea sativa (in samples Giresun, Rize 1, Rize 2, Rize 3, Rize 4 and Rize 5) detected as dominant (Table 1). For this reason, these honey samples can be described as chestnut honey. Pollens belonging to Alnus spp., Apiaceae, Asteraceae, Caryophyllaceae, Echium spp., Lamiaceae, Liliaceae, Pinaceae, Poaceae, Rosaceae, Scabiosa spp., Teucrium spp. taxa were observed in honey of Hakkari region. Also, pollens belonging to Asteraceae, Boraginaceae, Caryophyllaceae, Cephalaria spp., Echium spp., Fabaceae, Lamiaceae, Liliaceae Onobrychis spp. taxa were detected in honey of Erzurum region. 
420 | N. Ecem Bayram and E. Demir / Hacettepe J. Biol. \& Chem., 2018, 46 (3), 417-423

Table 1. Pollen spectrum, moisture (\%) and proline content $(\mathrm{mg} / \mathrm{kg})$ of honey samples.

\begin{tabular}{|c|c|c|c|}
\hline Sample Origin & Pollen spectrum & $\begin{array}{l}\text { Moisture } \\
(\%)\end{array}$ & $\begin{array}{l}\text { Proline } \\
\text { content } \\
(\mathrm{mg} / \mathrm{kg})\end{array}$ \\
\hline Giresun & $\begin{array}{l}* \quad \text { Castanea sativa MILLER. } \\
* * \quad- \\
* * * \quad- \\
* * * * \text { Apiaceae, Fabaceae }\end{array}$ & 22 & 692.88 \\
\hline Hakkari & $\begin{array}{l}\text { * Fabaceae } \\
\text { ** } \quad- \\
\text { *** - } \\
\text { **** Onobrychi spp., Pinaceae, Lamiaceae, } \\
\text { Rosaceae, Teucrium spp., Apiaceae, Liliaceae, } \\
\text { Echium spp., Caryophyllaceae, Poaceae, Scabiosa spp., } \\
\text { Apiaceae, Alnus spp., Asteraceae }\end{array}$ & 17 & 696.09 \\
\hline Rize 1 & $\begin{array}{l}* \quad \text { Castanea sativa MILLER } \\
* * \quad \text { Brassicaceae, } \\
* * * \\
\text { **** Tilia spp, Ericaceae, Poaceae, Caryophyllaceae, Fabaceae }\end{array}$ & 19.4 & 526.61 \\
\hline Rize 2 & $\begin{array}{l}\text { * } \quad \text { Castanea sativa MILLER. } \\
* * \quad \text { Brassicaceae } \\
* * * \quad- \\
* * * * \text { Fabaceae, Poaceae, Rhododendron spp., Rosaceae }\end{array}$ & 18.6 & 503.46 \\
\hline Rize 3 & $\begin{array}{l}* \quad \text { Castanea sativa MILLER. } \\
* * \quad- \\
* * * \quad- \\
* * * * \text { Ericaceae, Fabaceae, Rosaceae, Myosotis spp., Rumex } \\
\text { spp. }\end{array}$ & 19.8 & 640 \\
\hline Rize 4 & $\begin{array}{l}* \quad \text { Castanea sativa MILLER. } \\
* * \quad- \\
* * * \quad- \\
* * * * \text { Rosaceae, Ericaceae, Fabaceae }\end{array}$ & 17.8 & 682.66 \\
\hline Rize 5 & $\begin{array}{l}* \quad \text { Castanea sativa MILLER. } \\
* * \quad- \\
* * *- \\
* * * * \text { Rosaceae, Fabaceae, Poaceae, Citrus spp., Rhododendron } \\
\text { spp. }\end{array}$ & 19.1 & 622.93 \\
\hline Erzurum & $\begin{array}{l}* \\
* * \quad \text { Fabaceae } \\
* * * \quad \text { Lamiaceae, Boraginaceae } \\
\text { **** Cephalaria spp., Echium spp., Onobrychis } \\
\text { spp.,Asteraceae, Caryophyllaceae, Liliaceae }\end{array}$ & 16 & 617.76 \\
\hline
\end{tabular}


It has been reported that the plant taxa forming the source of flower honey produced in Turkey are Asteraceae, Fabaceae, Fagaceae Myrtaceae, Malvaceae, Brassicaceae, Scrophulariaceae, Lamiaceae and Oleaceae families [26]. Similarly, in a research conducted with Rize-Ayder Plateau honey samples, the pollen of Castanea sativa plant was found intensively together with the pollen of Ericaceae, Rosaceae, Brassicaceae, Fabaceae and Boraginaceae families [27]. Erdoğan [28] found that Castanea sativa pollen was dominant in 25 out of 65 samples. Unlike our study, Çam [29], as a result of pollen analysis he carried out on some honey samples found in the market, detected the pollen belonging to the family Compositae in predominantly lager amounts [29]. According to the results of melissopalynological analysis of our study, it was determined that Giresun and Rize honey were monofloral and others were multifloral honey samples. Since this situation may be related to Turkey's floral richness, honey's floral sources and physicochemical properties vary considerably by region [30].

In addition to melissopalynological analysis, authenticity of honey can be understood [31] by various techniques such as determining the proline content of honey, potassium and sodium ratio $(\mathrm{K} / \mathrm{Na})$ and total pollen spectrum [1].

The amino acid profile of honey samples collected from different regions may be an indication of the floral origins of honey [32]. The protein content of the flower honey is approximately $0-1.5 \%$, while this ratio in the honeydew honey is about $3.0 \%$. The amount of amino acids is about $1 \%$, and proline is the main constituent that makes up $50-85 \%$ of the total amino acid content [32] which is depends on the origin of the honey (nectar or honeydew). Proline originates from the salivary secretions of honey bees during nectar conversion [33]. The amount of proline is important not only as a criterion in determining the quality value and maturity of the honey, but also in determining the detection of its adulteration with sugar. In Germany, honey with a proline content lower than $18.0 \mathrm{mg} / 100 \mathrm{~g}$ is considered to have undergone adulteration or not mature [34]. For this reason, proline content is one of the main criteria used to evaluate the quality of honey and the counterfeiting in honey and according to the Turkish Food Codex Honey Communiqué [35] the content of proline in honey should not be less than $300 \mathrm{mg} / \mathrm{kg}$. In our study, proline values of honey samples were determined as $617.76 \mathrm{mg} / \mathrm{kg}$ (Erzurum), 692.88 $\mathrm{mg} / \mathrm{kg}$ (Giresun), $696.09 \mathrm{mg} / \mathrm{kg}$ (Hakkari), 526.61 $\mathrm{mg} / \mathrm{kg}$ (Rize 1), $503.46 \mathrm{mg} / \mathrm{kg}$ (Rize 2), $640 \mathrm{mg} / \mathrm{kg}$ (Rize 3), $682.66 \mathrm{mg} / \mathrm{kg}$ (Rize 4) and $622.93 \mathrm{mg} / \mathrm{kg}$ (Rize 5). The proline content in the honey samples varied from $503.46 \mathrm{mg} / \mathrm{kg}$ to $696.09 \mathrm{mg} / \mathrm{kg}$ and the highest was observed in Hakkari and Giresun honey, respectively. Yılmaz and Küfrevioğlu [36] found proline values in the range of $300-860 \mathrm{mg} /$ $\mathrm{kg}$ in their studies on honey collected from the Eastern and Southeastern Anatolia Regions. It was determined that the proline content of honey samples in the North Eastern Anatolia Region of Turkey (Erzurum, Narman, Oltu, Tortum) was between $443-715 \mathrm{mg} / \mathrm{kg}$ [37]. Czipa et al. [32] found that the proline value of acacia honey was the lowest (average $242 \mathrm{mg} / \mathrm{kg}$ ) and cilantro and honeydew honey were the highest (average 2283 $\mathrm{mg} / \mathrm{kg}$ and $1089 \mathrm{mg} / \mathrm{kg}$, respectively) in proline analysis of 143 honey samples of different plant origin obtained from countries such as Hungary, Tasmania, New Zealand, Malaysia, Thailand, South Africa, Finland. Oddo and Piro [38] reported that they found an average proline amount of $468 \mathrm{mg} /$ $\mathrm{kg}$ in 721 honeydew honey samples. Manzanares et al. [39] found proline values in the range of 664$1689 \mathrm{mg} / \mathrm{kg}$ in pine honey and 310-1057 mg/kg in flower honey. In our study, the moisture content of honey samples was determined to be between $16 \%$ $-22 \%$. Moisture ratio was found to be significantly higher in chestnut honey compared to multifloral honey (Table 1).

As a result, in order to be able to use proline values of honey samples according to the regions in distinguishing, it is necessary to work with more samples to say something definite. In addition, the proline content of honey samples is higher than the values specified in Turkish Food Codex Honey Communiqué [35], which may be an indication of their purity and quality. 


\section{References}

1. C. Mutlu, M. Erbaş, S. A. Tontul, Bal ve diğer arı ürünlerinin bazı özellikleri ve insan sağlığı üzerine etkileri, Akademik Gıda, 15 (2017) 75-83.

2. J. McCarthy, Antibacterial effects of honey: medical fact or fiction?. American Bee Journal, 135 (1995) 341342.

3. F.D. Halstead, M. A. Webber, M. Rauf, R. Burt, M. Dryden, B. A. Oppenheim, In vitro activity of an engineered honey, medical-grade honeys, and antimicrobial wound dressings against biofilm-producing clinical bacterial isolates, Journal of Wound Care, 25 (2016) 93-102.

4. A. Meda, C. E. Lamien, M. Romito, J. Millogo, O. G. Nacoulma, Determination of the total phenolic, flavonoid and proline contents in Burkina Fasan honey, as well as their radical scavenging activity, Food Chem., 91(2005) 571-577.

5. O. Escuredo, M. Míguez, M. Fernández-González, M. C. Seijo, Nutritional value and antioxidant activity of honeys produced in a European Atlantic area, Food Chem., 138 (2013) 851-856.

6. I. Hermosı n, R. M. Chicon, M. D. Cabezudo, Free amino acid composition and botanical origin of honey. Food Chemistry, 83 (2003) 263-268.

7. K. Sorkun, Ö. Gençay-Çelemli, Ç. Özenirler, N. EcemBayram, F. Güzel, Palynological investigation of honey produced in Ardahan-Turkey, Bee World, 91 (2014) 8083.

8. S. Silici, M. Gökceoglu, Pollen analysis of honeys from Mediterranean region of Anatolia, Grana, 46 (2007) 57-64.

9. A. Belay, G. D. Haki, M. Birringer, H. Borck, A. Addi, K. Baye, S. Melaku, Rheology and botanical origin of Ethiopian monofloral honey, LWT-Food Science and Technology, 75 (2017) 393-401.

10. E. Anklam, A review of the analytical methods to determine the geographical and botanical origin of honey, Food Chem., 63 (1998) 549-562.

11. M. J. Nozal, J. L. Bernal, M. L. Toribio, J. C.Diego, A. Ruiz, Rapid and sensitive method for determining free amino acids in honey by gas chromatography with flame ionization or mass spectrometric detection, Journal of Chromatography A, 1047 (2004) 137-146.

12. L. S. Chua, J. Y. Lee, G. F. Chan, Characterization of the proteins in honey, Analytical letters, 48 (2015) 697-709.

13. A. J. Tonks, R. A. Cooper, K. P. Jones, S. Blair, J. Parton, A. Tonks, Honey stimulates inflammatory cytokine production from monocytes, Cytokine, 21 (2003) 242-247.

14. N. Yusof, A. H. Ainul Hafiza, R. M. Zohdi, M. Z. A. Bakar, Development of honey hydrogel dressing for enhanced wound healing, Radiat. Phys. Chem, 7676 (2007) 1767-1770.

15. B. Kaplan, Ege Bölgesi Ballarının Kimyasal Özellikleri, Ege Üniversitesi Fen bilimleri Estitüsü,Yüksek Lisans Tezi, 2014
16. M.I. Haroun, Türkiye'de Üretilen Bazı Çiçek ve Salgı Ballarının Fenolik Asit ve Flavonoid Profilinin Belirlenmesi. Doktora Tezi. Ankara Üniversitesi Fen Bilimleri Enstitüsü, 2006.

17. A. E. Sunay, Balda orijin tespiti. Yüksek Lisans Tezi. İstanbul Teknik Üniversitesi. 2006.

18. W. Von der Ohe, J. H. Dustmann, K. Von der Ohe, Prolin als kriterium der reife des honigs, Deutsche Lebensmittel-Rundschau, 87(1991) 383-386.

19. F. Karadal, Y. Yıldırım, Balın kalite nitelikleri, beslenme ve sağlık açısından önemi, J Fac Vet Med Univ Erciyes 9 (2012) 197-209.

20. J. Louveaux, A. Maurizio, G. Vorwohl, Internationale Kommission für Bienenbotanik der IUBS methodik der melissopalynologie, Apidologie, 1 (1970)193-209.

21. Ö. Gençay-Çelemli, Ç. Özenirler, N. Ecem-Bayram, G. Zare, K. Sorkun, Melissopalynological analysis for geographical marking of Kars Honey, Kafkas Üniversitesi Veteriner Fakültesi Dergisi, 24 (2018) 5359.

22. N. Mayda, A. Özkök, K. Sorkun, Some Characteristic Properties of Chestnut and Rhododendron Honeys in Turkey, Hacettepe J. Biol. \& Chem., 46(2018) 135-145.

23. S. Bogdanov, Harmonised methods of the international honey commission, International Honey Commission (IHC), (2002) 1-62.

24. J. Devillers, M. Morlot, M. Pham-Delegue, J. Dore, Classification of monofloral honeys based on their quality control data, Food Chem., 86 (2004) 305-312.

25. Harmonized methods of the international honey comission. Swiss Bee Research Centre Bern, Switzerland: 1-61, 1997.

26. Sorkun, K., Doğan, C., Gümüş, Y., Başoğlu, N., Bulakeri, N. ve Ergün, K. Türkiye'de üretilen doğal ve yapay kaynaklı balların ayırt edilmesine esas olacak fiziksel, kimyasal ve palinolojik kriterlerin belirlenmesine yönelik araştırmalar; Tübitak Tarım, Orman ve Gıda Teknolojileri Araştırma Grubu, Proje no:TOGTAG-1270, Bursa, 1999.

27. E. Demir, The chemical and palynological characteristic of honey kind of the district and Ayder-Ceymakçur (Camlihemşin/Rize), Recep Tayyip Erdoğan Üniversitesi Fen Bilimleri Enstitüsü, Yüksek Lisans Tezi, 2013.

28. N. Erdoğan, Adapazarı Ballarında Polen Analizi, Yüksek Lisans Tezi, Ankara, Türkiye, 2007.

29. B. Çam, Ankara Piyasasında Bulunan Bazı Ballarda Polen Analizleri ve Bu Balların Antimikrobiyal Özellikleri, Yüksek Lisans Tezi, Ankara, Türkiye, 2006.

30. C. Ozenirler, N. Ecem-Bayram, O. Gencay-Celemli, O. Celikbicak, , K. Sorkun, Chemical characterization of Kars honey. Fresenius Environmental Bulletin, 27 (2018) 1889-1895.

31. E. Corbella, D. Cozzolino, Combining multivariate analysis and pollen count to classify honey samples accordingly to different botanical origins, Chilean Journal of Agricultural Research, 68 (2008) 102-107.

32. N. Czipa, M. Borbély, Z. Gy ri, Proline content of different honey types, Acta Alimentaria, 41 (2012) 2632. 
33. P. M. da Silva, C. Gauche, L. V. Gonzaga, A. C. O. Costa R. Fett, Honey, Chemical composition, stability and authenticity, Food Chem, 196 (2016) 309-323.

34. S. Bogdanov, K. Ruoff, L. Persano Oddo, Physicochemical methods for the characterization of unifl oral honeys: a review, Apidologie, 35 (2004) 4-17.

35. Codex, T.F., Turkish Food Codex, Honey Notification (2012). T.C. Ministry of Agriculture and Rural Affairs (no: 2012/58) 2012.

36. H. Yılmaz, ì. Küfrevioğlu Composition of honeys collectedf eastern and south-eastern anatolia and effect of storage on hydroxymethylfurfural content and diastase activity, Turkish J Agric Forest, 25(2001) 347-349.
37. M. M. Cengiz, M. Tosun, M. Topal, Determination of the physicochemical properties and $13 \mathrm{C} / 12 \mathrm{C}$ isotope ratios of some honeys from the northeast Anatolia region of Turkey, J Food Comp Analy, 69 (2018) 39-44.

38. L.P. Oddo, R. Piro, Main European unifloral honeys descriptive sheets. Apidologie, 31 (2004) 38-45.

39. A. B. Manzanares, Z. H. García, B. R. Galdón, E. R. Rodríguez, C. D. Romero, Differentiation of blossom and honeydew honeys using multivariate analysis on the physicochemical parameters and sugar composition. Food Chem, 126 (2011) 664-672. 